\title{
PEMBENTUKAN RESILIENSI (RESILIENT FORMATION) PADA PENDERITA THALASSEMIA
}

\author{
Yudi Kurniawan (07320112) \\ Jurusan Psikologi Fakultas Psikologi dan Ilmu Sosial Budaya Universitas \\ Islam Indonesia
}

\begin{abstract}
Thalassemia is a genetic disorder within haemoglobin formation that cause its patients were given blood transfusion along their life. It make thalassemia patients having difficulties for doing activity and self-actualization. Thalassemia. patient in Indonesia increase rapidly within ten years lately (TEMPO magazine January $17^{\text {th }} 2010$ edition). This research have been used qualitative method with case study design. It is aimed for exploring resilient formation and resilient determinant within thalassamia patients. There are two respondents (thalassemia patient) attain the age of 19 and 20 years old who have been interviewed in this research. Data in this research were collected by indepth interview. Data were analysed using open and axial coding. Result in this research showed that resilience is formed by four resilient determinants. There are support from significant others, individual spiritual factor, competent factor, and goal-seeking. Resilient formation process consists of resilient determinant key factor, adaptive strategies, optimized resilient determinant, and moving forward. Trust and support from family are the key factor of resilient process and also be a resilient foundation for each respondent.
\end{abstract}

Keywords: Resilient formation, resilient determinant, thalassemia

\section{PENGANTAR}

Thalassemia adalah penyakit keturunan (genetik) yang terkait dengan pembentukan sel darah merah pada tubuh manusia. Penderita thalassemia tidak hanya kekurangan sel darah merah (hemoglobin), namun juga tidak memiliki sel darah merah yang sehat dalam jumlah cukup. Sel darah merah tersebut terbentuk tidak sempurna dan tidak mengandung cukup hemoglobin. Akibatnya, sel darah merah yang sakit tidak mampu memberikan oksigen yang diperlukan oleh tubuh penderita. Dampak fisik yang terlihat adalah penderita tidak sanggup melakukan 
aktivitas fisik berat dan kulit yang menghitam akibat penumpukan zat besi pada tubuh (Lena, dkk, 1997).

Badan Oganisasi Kesehatan Dunia (WHO) mengungkapkan bahwa thalassemia digolongkan sebagai penyakit keturunan terbanyak di dunia. Penyakit ini banyak ditemukan di kawasan Laut Tengah, Timur Tengah, dan Asia. Data WHO menunjukkan bahwa 4,5 persen penduduk dunia ( \pm 250 juta orang) membawa sifat genetik thalassemia. Jumlah tersebut terus bertambah karena ada 300 ribu anak di dunia yang menderita thalassemia setiap tahunnya. Hingga kini belum ada obat yang mampu menyebuhkan thalassemia. Seseorang yang terdiagnosa thalassemia harus menjalani transfusi darah setidaknya sebulan sekali sepanjang usia hidupnya (available at www.inilah.com, diakses 23 Januari 2011).

Indonesia termasuk negara yang menjadi persebaran utama thalassemia. Jumlah penderita thalassemia di Indonesia juga mengalamai kenaikan. Pada 1994, jumlah penderita yang terdata sebanyak 500 orang. Dalam rentang waktu empat belas tahun (2008), jumlah tersebut bertambah 3 kali lipat menjadi 1500 orang. Jumlah ini diprediksi akan meningkat tajam menjadi 22.500 penderita pada tahun 2020 nanti. Saat ini sekitar 3 hingga 10 persen dari seluruh populasi masyarakat Indonesia membawa sifat thalassemia. Artinya, tiga dari seratus orang di Indonesia berpotensi meneruskan penyakit thalassemia ke generasi berikutnya (Majalah TEMPO edisi 17 Januari 2010).

Sayangnya perhatian pemerintah lebih banyak tertuju pada penyakit infeksi seperti HIVIAIDS dan kanker daripada penyakit genetik seperti thalassemia. Tidak heran jika jumlah penderita thalassemia di Indonesia terus mengalami kenaikan dalam rentang waktu beberapa tahun. Secara awam, AIDS dan kanker lebih terlihat mematikan daripada thalassemia. Padahal penyakit infeksi dan penyakit genetik seperti thalassemia sama-sama menurunkan daya tahan tubuh penderitanya.

Mayoritas penderita thalassemia memiliki fisik yang lemah dan tidak dapat berkembang seperti orang normal. Penderita juga harus menempuh pengobatan dan transfusi darah sekali sebulan selama usia hidupnya. Walaupun saat ini kualitas pengobatan thalassemia semakin berkembang, masih banyak penderita yang menghabiskan waktu dengan berdiam diri dan tidak mampu mengaktualisasikan dirinya. Minimnya informasi tentang thalassemia juga membuat keluarga penderita cenderung tidak berani membiarkan penderita melakukan aktivitas fisik yang berat.

Menariknya berdasarkan penelusuran peneliti pada peguyuban thalassemia Yogyakarta, ada dua orang penderita thalassemia usia dewasa yang tetap mampu beraktivitas normal bahkan mampu melanjutkan pendidikan hingga pergutuna tinggi. 
Kondisi kedua penderita ini membuat peneliti tertarik mengkaji secara psikologis terhadap faktor yang membuat mereka mampu bertahan dan bangkit dalam kondisi tidak menguntungkan. Apalagi peneliti belum menemukan referensi terkait penelitian thalassemia dalam konteks psikologis. Secara psikologis, individu yang mampu bangkit dari kondisi sulit dinamakan orang yang resilien. Sifat tersebut terkait dengan istilah resiliensi.

Karakteristik resiliensi muncul pada individu yang mampu meminimalisir faktor risiko yang timbul akibat peristiwa traumatik atau kondisi fisik yang tidak menguntungkan (cacat atau penyakit genetik) dengan mengotimalkan faktor protektif, sehingga ia bisa bangkit dari kondisi tidak menguntungkan. Individu yang resiliensi mampu menemukan aktualisasi dirinya. Apa yang ditemukan sebagai faktor protektif pada seseorang bisa saja menjadi faktor risiko bagi orang yang lain. Proses resiliensi yang terjadi pada setiap individu bisa bersifat unik (Rutter; Bogar\&Killacky, 2006).

Hollister-Wagner (Everall dkk, 2006) menyebutkan bahwa resiliensi adalah istilah yang digunakan untuk menjelaskan sifat dasar seseorang yang mampu memproteksi dirinya dari efek negatif risiko dan kemampuan bertahan menghadapi masalah. Resiliensi terbentuk karena ada faktor protektif dan faktor risiko yang muncul pada individu. Pada akhirnya, dominasi faktor protektif pada individu akan meminimalisir kemunculan faktor risiko. Faktor protektif bisa dalam bentuk apa saja, selama faktor tersebut membantu individu untuk bangkit dari masalahnya. Hal sebaliknya terjadi dengan faktor risiko.

Skripsi ini berdasarkan penelitian dari Bogar dan Killacky (2006) mengenai faktor penentu resiliensi. Istilah ini sama dengan konsep faktor protektif, hanya saja kemunculannya spesifik pada penelitian kualitatif. Responden dalam penelitian Bogar dan Killacky adalah wanita yang pernah mengalami kekerasan seksual di masa kanakkanak. Bogar dan Killacky mengungkapkan mengenai lima hal yang menjadi faktor penentu resiliensi, yaitu competent, high-self regard, helpful life circumstance, interpersonally skilled, dan spiritual. Bogar dan Killacky juga menjelaskan empat proses yang dilalui individu untuk mencapai resiliensi yaitu coping strategies, refocusing and moving on, active healing, dan achieving closure.

Peneliti tertarik untuk mengetahui bagaimana proses pembentukan resiliensi dan faktor penentu resiliensi apa saja yang terdapat pada pénderita thalassemia. Maka peneliti menjadikan penelitian Bogar dan Killacky sebagai landasan teori utama karena kesamaan konteks penelitian. Penelitian ini penting karena bisa digunakan sebagai langkah kuratif (penolong) bagi penderita thalassemia. Hasil penelitian ini terutama memang diperuntukkan bagi penderita thalassemia yang belum 
bangkit dari kondisi risiko agar mereka mampu mengaktualisasikan dirinya. Hal inilah yang menjadi latar belakang sekaligus tujuan dari penelitian ini.

\section{TINJAUAN PUSTAKA}

Rutter (Bogar dan Killacky, 2006) menjelaskan bahwa resiliensi adalah konsep psikologis yang merupakan kombinasi antara kepribadian dasar dengan pengaruh lingkungan, dimana kombinasi tersebut memberikan perlindungan bagi individu dari efek psikologis yang berbahaya akibat trauma atau tekanan yang sangat hebat.

Definisi lain diungkapkan oleh Wisner (Rodriguez \& Aguirre, 2006). la memberikan penjelasan bahwa resiliensi adalah kemampuan "bounce back"'(melenting kembali) dan kembali pada fungsi normal sebagai individu. Individu yang resilien mampu menggunakan bantuan dari lingkungan untuk menyelesaikan masalah.

Bogar dan Killacky (2006) menjelaskan istilah resilient determinant yang merujuk pada 5 faktor penentu yang membuat seseorang mampu bertahan pada situasi traumatis dan menekan serta kembali pada kontinum normal sebagai manusia seutuhnya. Faktor penentu resiliensi (resilient determinant) ini sama dengan faktor protektif; hanya saja kemunculannya lebih kasuistik sesuai dengan hasil penelitian kualitatif yang dilakukan oleh Bogar dan Killacky. Lima faktor penentu tersebut adalah: a) Interpersonally skilled

Kemampuan interpersonal adalah faktor pertama yang membuat seseorang mampu beriteraksi secara positif dengan orang lain. Kemampuan ini bisa menggiring kondisi psikologis individu pada kebahagiaan dan kesenangan.

b) Competent

Kompetensi adalah gabungan antara bakat dan kerja keras. Individu yang menggunakan bakat serta berusaha keras untuk terus mengasahnya, maka ia akan mampu menjadi individu yang berkompeten dan mampu bersaing secara positif dengan manusia lainnya.

c) High Self Regard

Setiap manusia pasti memiliki banyak kelemahan dalam dirinya. Namun dengan penerimaan diri yang positif, setiap kelemahan tersebut dapat tertutupi dengan kelebihan dan mampu menerima diri apa adanya.

d) Spiritual

Keyakinan spiritual menjadi penting untuk membentuk individu menjadi resilien karena keyakinan spiritual membuat manusia menerima peristiwa traumatis yang menimpanya.Keyakinan spiritual membuat individu yakin bahwa ada yang mengatur setiap peristiwa yang terjadi di alam semesta ini.

e) Helpful Life Circumstance

Lingkungan yang mendukung juga sangat membantu seseorang 

Yudi

untuk menjadi resilien. Lingkungan disini dapat diartikan sebagai keluarga dan orang-orang terdekat. Selain dukungan dari lingkungan, helpful life circumstance muncul dalam bentuk peristiwa yang menentukan dan menjadi titik balik bagi individu untuk menjadi resilien. Kelima faktor tersebut muncul dari beberapa tahapan proses sebagai berikut (Bogar dan Killacky, 2006):

a) Coping Strategies

Setiap individu memiliki cara pemecahan masalah yang berbeda-beda. Pengembangan strategi pemecahan masalah telah terjadi sejak masa kanak-kanak hingga dewasa. Oleh karena itu, ketika individu berhadapan dengan peristiwa traumatik, strategi pemecahan masalah akan muncul dengan sendirinya. Proses ini akan mengawali penemuan terhadap faktor penentu yang dapat menggiring individu pada resiliensi.

b) Refocusing and Moving On

Tahapan berikutnya adalah kembali pada fokus dan bergerak maju untuk mencari cara agar bisa meninggalkan peristiwa traumatik dan kembali pada kondisi normal

c) Active Healing

Penyembuhan secara aktif dapat berupa memberikan sugesti-sugesti positif kepada diri sendiri dan visualisasi terhadap kebaikan yang ingin dicapai. Proses penyembuhan ini juga bisa dengan cara menge- nang peristiwa masa lalu yang sangat menyenangkan dan mempengaruhi individu

d) Achieving Closure

Ini adalah tahapan terakhir yang menjadi penutup bagi individu jika ingin melupakan peristiwa traumatik dan menjadi resilien. Tahap ini digambarkan dengan proses menutup rapat-rapat pintu masa lalu yang terkait dengan peristiwa traumatik. Bentuk tahapan ini bisa berupa pemaknaan kembali terhadap peristiwa traumatik di masa lalu dalam konteks yang lebih positif. Sementara itu, thalassemia adalah penyakit genetis yang diturunkan secara autosomal resesif menurut hukum Mendel dari orangtua kepada anakanaknya. Penyakit ini meliputi suatu keadaan dari gejala klinis gangguan sel darah merah yang disebut dengan thalassemia minor sebagai pembawa hingga thalassemia mayor untuk penderita (Ganie, 2005).

Bentuk heterozigot diturunkan oleh salah satu orangtua yang membawa sifat penyakit thalassemia. Sementara bentuk homozigot diturunkan oleh kedua orangtua yang membawa gen penyakit ini. Penyakit ini berbeda dengan anemia yang hanya kekurangan sel darah merah serta dapat diatasi dengan menambah asupan zat besi dari makanan. Penderita thalassemia tidak pernah mampu untuk memproduksi sel darah merah yang sehat (Ganie, 2005). 
Menurut Hoffbrand dkk (2002), sel darah merah (hemoglobin) penderita thalassemia dianalogikan seperti balon kempes yang tidak memiliki udara. Seharusnya hemoglobin mengembang utuh yang dapat digunakan untuk mengedarkan oksigen ke seluruh tubuh. Namun hemoglobin pada penderita thalassemia tidak sempurna, mudah pecah, dan tidak mampu mengedarkan oksigen secara maksimal ke seluruh tubuh. Oleh karena itu, penderita thalassemia yang sudah harus melakukan transfusi darah ditandai dengan semakin lemasnya kondisi tubuh.

Oleh karena itu, Ganie (2005) menjelaskan bahwa bahwa secara psikologis, individu yang terkena thalassemia rentan mengalami guncangan dan ketidakseimbangan emosi akibat kondisi fisik yang lemah seumur hidupnya. Hal tersebut dapat dikurangi apabila ada dukungan keluarga ataupun faktor pendukung lain yang mampu membuat individu dengan thalassemia tetap beraktivitas layaknya individu tanpa thalassemia.

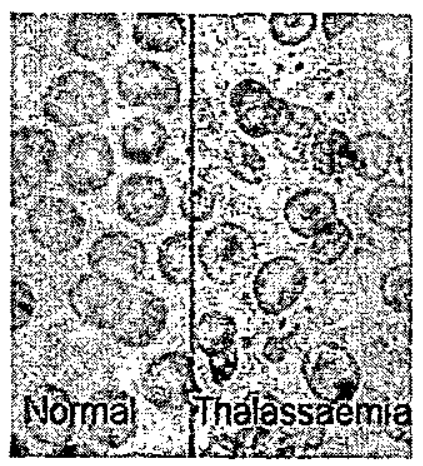

Gambar 1. Perbandingan sel darah normal dan sel darah penderita thalassemia
Menurut Isbisten dan Pittiglio (1999), jenis thalassemia dikelompokkan dalam tiga jenis yaitu:

a. Thalassemia Mayor

Thalasemia mayor disebabkan oleh kegagalan produksi rantai beta homozigot pada usia enam bulan. Bayi ini normal pada saat lahir dan penyakit baru timbul saat hemoglobin diproduksi. Namun seringkali ornagtua tidak mengetahui gejala thalassemia sehingga kondisi ini baru diketahui ketika anak berusia empat hingga lima tahun. Kerusakan sel darah merah pada penderita thalassemia mayor paling berat daripada jenis lainnya.

b.Thalassemia Intermedia

Jenis ini lebih ringan daripada thalassemia mayor. Biasanya mulai terlihat pada usia lima tahun. Kelebihan zat besi dapat menjadi masalah perkembangan fisik dengan pigmen empedu. Sel darah merah dalam kondisi tidak normal namun masih bisa berproduksi terus menerus.

c. Thalassemia Minor

Orang dengan thalassemia jenis ini hanya mengalami anemia ringan dan asimtomatik. Mereka bukan penderita namun pembawa sifat thalassemia yang akan diturunkan pada generasi setelahnya.

Thalassemia adalah penyakit genetik yang lazim terdiagnosa ketika seseorang berusia kanak-kanak atau bahkan saat masih bayi. Pada masa 
ini, individu secara mutlak membutuhkan perawatan, dukungan, dan penerimaan dari orang terdekatnya (keluarga dan orangtua) karena belum mampu untuk mencerna situasi secara abstrak. Grotberg (1999) juga memaparkan bahwa trust (kepercayaan) dari orang lain adalah fondasi bagi individu untuk melewati masa-masa penuh tekanan. Maka, dukungan dari lingkungan bisa menjadi faktor penentu pertama yang muncul pada penderita thalassemia yang resilien.

Berdasarkan pemarapan masalah dan kerangka teori, maka pertanyaan penelitian yang diajukan oleh peneliti adalah:

1. Apa saja faktor penentu resiliensi (resilient determinant) pada penderita thalassemia?

2. Bagaimana proses pembentukan resiliensi (resilient formation) pada penderita thalassemia?

\section{METODE PENELITIAN}

Penelitian ini menggunakan pendekatan kualitatif dengan desain penelitian studi kasus. Metode kualitatif menuntut peneliti untuk mengutamakan penjelasan yang cermat dalam melakukan analisis dan menyajikan temuannya. Prinsipnya adalah menjelaskan secara akurat tentang hal yang diteliti. Proses mengurangi dan menyusun materi ini merupakan seleksi dan interpretasi (Strauss \& Corbin, 2003).

Responden dalam penelitian ini ditentukan dengan purposive sampling dimana pemilihan sampel sesuai. dengan kebutuhan yang dikehendaki dalam penelitian. Subjek yang dipilih adalah orang-orang yang memiliki informasi khusus mengenai kasus yang diteliti (Newman, 2003). Adapun karakteristik subjek dalam penelitian ini adalah:

1. Penderita thalassemia yang memiliki aktivitas rutin, seperti mengajar dan bekerja (aktivitas selain proses pengobatan dan transfusi darah).

2. Penderita thalassemia yang minimal telah lima tahun terdiagnosa thalassemia dan memenuhi kriteria individu yang resilien. Hal ini diketahui melalui proses wawancara terhadap kedua subjek. Batasan waktu lima tahun adalah asumsi bahwa individu telah mengembangkan tahapan atau proses untuk menjadi resilien dengan beberapa strategi penyelesaian masalah (Bogar \& Killacky, 2006).

3. Usia subjek berada dalam rentang 18-25 tahun. Fase ini adalah transisi dari tahap remaja akhir ke tahap dewasa awal, dimana idealnya individu sudah membentuk identitas dan menemukan aktualisasi dirinya. Hal ini sesuai dengan karakteristik orang yang resilien.

Data dalam penelitian ini dikumpulkan dengan metode wawacara mendalam. Metode ini lazim digunakan dalam pendekatan kualitatif karena memungkinkan peneliti melakukan 
interaksi lebih dalam dan lebih dekat dengan subjek penelitian. Wawancara merupakan perangkat untuk memproduksi pemahaman situasional (situated understanding) yang bersumber dari episode-episode interaksional khusus (Denzin dan Lincoln, 2009).

Metode analisis data dalam penelitian ini adalah analisis kualitatif. Menurut Strauss dan Corbin (2003), setelah proses pengumpulan data dengan metode observasi dan wawancara dilanjutkan dengan analisis data. Analisis dan interpretasi yang digunakan untuk menghubungkan antara temuan lapangan dengan teori. Proses ini disebut dengan pengkodean (pengkodean).

\section{HASIL DAN PEMBAHASAN}

\section{Faktor-Faktor Penentu Resiliensi}

1. Dukungan dari Orang Terdekat

Dukungan dari orang terdekat merupakan bentuk modifikasi dari faktor helpful life circumstance yang terdapat pada teori acuan penelitian ini. Dukungan dari orang terdekat meliputi dukungan dan penerimaan dari keluarga inti (ayah, ibu, saudara), sahabat, pacar, dan guru. Berikut salah satu kutipan wawancara dengan responden:

"Menurut aku besar banget, karena selalu ada mereka. Ya nemenin kalau kisalnya lagi berobat. Ada yang nyariin donorlah. Ada yangnganterin ke rumah sakit...Ehm, dukungan, perhatian, ya selalu menenangkan hati." (W1, SR, 347-350, 353-354)
2. Spiritual

Spiritual adalah faktor yang terkait dengan keyakinan manusia yang menjadi kesatuan diri dengan alam semesta sehingga apapun yang terjadi adalah bentuk dari keharmonisan kehidupan. Dari hasil wawancara dengan responden pertama, faktor spiritual terdiri dari beberapa subfaktor seperti hubungan dengan Tuhan, penerimaan diri positif, dan refleksi diri. Berikut salah satu kutipan wawancara dengan responden:

"Kalau aku memandangnya nggak sebagai ujian. Malah sebagai anugerah. Kalau kita memandangnya sebagai ujian, maka kita akan semakin lemah. Tapi kalau kita memandangnya sebagai anugerah, maka kita akan lebih semangat." (W1, SR, 370-374)

\section{Kompetensi}

Kompetensi adalah kemampuan yang merupakan kombinasi antara faktor kepribadian, minat, dan keahlian yang dimiliki oleh responden. Kompetensi ini terkait pada pola interaksi responden dengan orang lain dan bagaimana cara responden mengaktualisasikan diri. Berikut salah satu kutipan wawancara dengan responden:

"Buat program. Terus desain grafis. Web desain, nulis cerpen, nulis puisi juga kadang-kadang... Ya, ada yang online di blog dan juga 
ada yang di file komputer offline." (W1, SR, 78-79, 81-82)

\section{Memiliki Cita-Cita}

Faktor ini menjadi salah satu pembentuk resiliensi yang membuat responden terus bersemangat menjalani kehidupan karena ada yang ia cita-citakan. Cita-cita ini terkait dengan keinginan responden untuk mengembangkan keahliannya agar menjadi sesuatu yang bisa bermanfaat dan membuat dirinya mandiri secara finansial. Berikut salah satu kutipan wawancara dengan responden penelitian:

“... Emm.. Bisnis...Software, desain. Masih berhubungan dengan komputerlah"(W1, SR, 415, 417-418)

\section{Dinamika Pembentukan Resiliensi} pada Responden Penelitian

Resiliensi terbentuk dari keunggulan faktor penentu dalam mengurangi efek risiko yang ditimbulkan oleh tekanan psikologis. Responden pertama, berinisial SR, terdiagnosa thalassemia pada usia lima tahun. Saat itu SR dan orangtuanya berdomisili di Jakarta. Mahalnya biaya pengobatan dan trasnfusi darah di Jakarta menjadi alasan bagi ibu SR untuk memutuskan pindah ke Yogyakarta. Sementara ayah SR tetap bekerja di Jakarta.

Memasuki masa SMP, SR mulai mendapatkan penolakan dari teman sebayanya. Penolakan ini-muncui akibat kesalahpahaman terhadap penyakit thalassemia. Apalagi saat SMP kondisi fisik SR mulai berubah, seperti kulit yang menghitam dan perut yang membesar. SR tidak pernah diacuhkan ketika ia ingin berbicara dengan teman-temannya. la bahkan selalu ditolak jika ada tugas sekolah yang harus diselesaikan secara berkelompok.

Responden kedua, berinisial NN, terdiagnosa thalassemia pada usia lima tahun. Sama seperti responden pertama, sejak usia tersebut ia juga menjalani proses pengobatan dan transfusi darah secara rutin. NN dan keluarganya berdomisili di Klaten. Oleh karena itu, NN harus bolak-balik ke Yogyakarta untuk pengobatan dan transfusi darah. Namun saat ini telah ada rumah sakit yang menyediakan fasilitas pengobatan bagi penderita thalassemia di Klaten.

Ketika duduk di bangku SD, NN masuk dalam kategori siswa yâng mendapatkan peringkat bagus di kelasnya. Sama seperti responden pertama, NN tidak dapat mengikuti pelajaran olahraga karena hambatan fisik. Pada masa SD ini, NN sangat takut jika harus menjalani pengobatan dan transfusi darah. Bagi NN, proses tersebut sangat menyakitkan. Apalagi setiap hari ketika pulang sekolah, ia harus diberikan infus sebagai bagian dari pengobatan. Kondisi ini praktis membuat NN tidak dapat bermain bebas seperti teman-teman seusianya. Setiap pulang sekolah ia hanya ber- 
diam diri di rumah karena harus diinfus. Ketakutan yang dihadapi NN ketika proses pengobatan dan transfusi darah hanya dapat hilang ketika ada orangtua yang menenangkannya.

Sejak awal terdiagnosa thalassemia, orangtua menjadi figur yang selalu memberikan dukungan bagi NN. Pada fase inilah dukungan dan penerimaan dari keluarga memegang peran yang sangat penting. Dukungan keluarga ini menjadi fondasi awal bagi kebangkitan mental responden di masa depan. Dukungan keluarga juga menjadi faktor penentu yang berasal dari lingkungan responden. Responden memang membutuhkan dukungan dan penerimaan dari orang-orang terdekatnya, terutama keluarga, karena ia belum bisa memahami penyakit thalassemia.

Keahlian yang telah dimiliki oleh responden membuat ia ingin menggelutinya secara lebih profesional di masa depan. la bercita-cita untuk bekerja pada bidang yang mereka senangi. NN ingin menjadi guru dan mengabdikan dirinya bagi dunia pendidikan. Sebagai seorang manusia, NN juga berkeinginan untuk membangun sebuah keluarga. NN sadar dengan risiko sebagai penderita thalassemia. Maka ia menginginkan ada proses pengecekan darah dengan pasangan sebelum pernikahan. Pada akhirnya, NN tetap pasrah kepada Sang Pencipta, bahwa thalassemia yang diberikan kepada mereka ini adalah sebuah anugerah, bukan ujian.
Keadaan dalam kehidupan responden ikut memberi proteksi dari kerentanan biologis. Keadaan pertama adalah dukungan orangtua agar responden tetap bersemangat sekalipun ia menderita thalasemia. Keadaan ini memiliki efek terbukanya penerimaan diri. Bahkan responden pertama bisa memiliki pacar yang benar-benar memahami kondisi penyakitnya. Hubungan responden pertama dengan pacarnya telah disetujui oleh kedua orangtua.

Faktor ini tidak sama persis dari acuan yang ada pada teori. Bogar dan Killacky (2006) menyebut faktor ini dengan istilah helpful life circumstance. Faktor tersebut adalah kombinasi dari peristiwa-peristiwa yang mempengaruhi kehidupan individu dengan dukungan dari lingkungan. Pada kasus penderita thalassemia, peneliti lebih melihat faktor dukungan dari keluarga sangat menonjol sehingga bisa dijadikan faktor kunci penentu resiliensi. Sementara peristiwa-peristiwa yang berpengaruh dalam kehidupan responden tercakup dalam dinamika hidup penderita thalassemia yang menjadi temuan dalam penelitian ini.

Kemudian faktor spiritual tidak hanya dikaitkan dengan ritual ibadah, tapi lebih kepada perilaku responden yang memperlihatkan bahwa ia yakin dengan campur tangan Tuhan dalam kondisi dirinya serta mengenai efek kausalitas dari apapun perbuatan yang telah ia lakukan (Adz Zakiey, 2007). Kedua responden menyatakan bahwa 
mereka yakin bahwa thalassemia adalah anugerah Tuhan yang diberikan dengan cara berbeda dari orang normal. Keyakinan ini membuat mereka bersyukur dan bisa menjalani kehidupan dengan menumbuhkan harapan baru. Spiritual termasuk dalam faktor penentu yang berasal dari diri responden (Within the child).

Sikap adaptasi tersebut bergerak menuju kedewasan psikologis. G. W. Allport, yang dikutip Sarwono dalam buku Psikologi Remaja, (Sarwono, 2010) memaparkan ciri psikologis kedewasaan berupa kemampuan untuk melihat diri sendiri secara objektif yang ditandai dengan kemampuan untuk memiliki wawasan tentang diri sendiri dan kemampuan untuk menangkap humor. Termasuk ketika dirinya menjadi sasaran olok-olokan. la tidak marah ketika dikritik dan pada saat yang diperlukan ia bisa melihat keadaan dirinya sebagai orang luar. Sikap tersebut tumbuh seiring dengan usaha responden untuk melakukan strategi adaptasi.

Pada acuan teori yang digunakan, faktor penentu kompetensi terkait dengan kemampuan khusus yang dimiliki oleh individu untuk membantu pengembangan potensi dirinya. Namun dalam penelitian ini, kompetensi terkait juga dengan kemampuan responden dalam menjalin relasi sosial.

Bagian pertama adalah kemampuan interpersonal yang termasuk dalam kategori protective factor within the child (Shonkoff \& Meisels, 2000).
Faktor penentu yang berasal dari dalam diri individu, terutama ketika individu tersebut beranjak dewasa, menjadi prediktor paling kuat dalam pembentukan resiliensi. Faktor penentu internal cenderung stabil dan kemunculannya tidak berdasarkan pengaruh lingkungan, melainkan keinginan internal dari responden. Kemampuan ini terkait juga dengan sikap asertif responden sehingga mereka mampu menyampaikan apa yang mereka rasakan kepada orang lain. Faktor ini membantu responden untuk menyelesaikan masalah trauma akibat pengobatan dan masalah penolakan dari teman-teman di sekolahnya.

Faktor penentu memiliki cita-cita membuat responden bisa memetakan pola kehidupannya di masa depan. Faktor ini juga membuat responden memiliki fokus dalam aktualisasi diri. Dengan harapan, mereka juga tetap konsisten mengembangkan minat. Walaupun mereka menderita thalassemia, mereka tetap bersemangat menempuh pendidikan dan melakukan sesuatu untuk masa depannya. Mereka memang bercita-cita untuk menjadi seseorang yang profesional di bidang yang menjadi minat masing-masing. Faktor ini terkait dengan fokus kedua responden pada minat dan pengembangan keahlian tertentu. Sehingga setelah mereka menguasai keahlian tertentu, mereka ingin untuk menjadi profesional dalam bidang tersebut.

Keadaan ini sesuai dengan pema- 
paran Grotberg (1999) bahwa jika individu tidak mampu mengembangkan kemampuannya, terutama dalam proses pendidikan formal dan hubungan pertemanan, maka individu tersebut akan bersikap inferior. Inferioritas ini berdampak padá ketidakyakinan dalam menghadapi masa depan. Harapan ini juga membantu responden untuk mengeliminasi faktor risiko (thalassemia dan kerentanan fisik) yang memang tidak pernah. Misalnya harap- an responden untuk berkeluarga. Secara medis telah diketahui bahwa pasangan yang menderita thalassemia pasti akan memiliki anak yang juga thalassemia. Namun hal ini tidak lagi menjadi halangan responden untuk memiliki cita-cita berkeluarga karena mereka telah diberikan kepercayaan dari lingkungannya.

Dinamika pembentukan resiliensi pada penderita thalassemia dapat dijabrkan dalam bagan berikut:

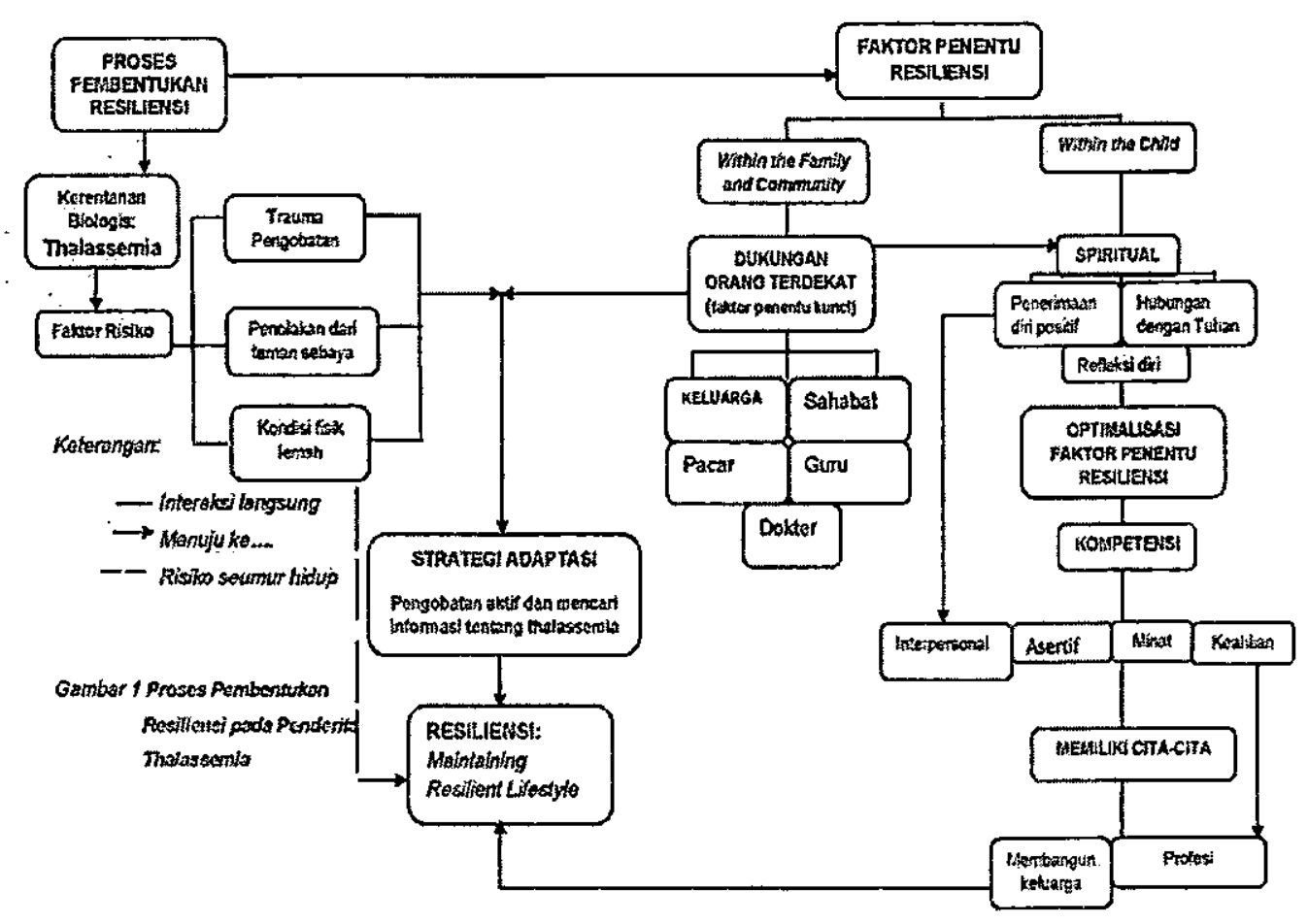

Gambar 1 Proses Pembentukan Resiliensi pada Penderita Thalassemia 
Kedua responden memiliki biological vulnerability (kerentanan biologis) yang membuat mereka hidup dengan thalassemia dan harus menjalani transfusi darah seumur hidup. Kerentanan ini menimbulkan faktor risiko yang, jika tidak dihambat, berpeluang mengganggu proses perkembangan psikologis mereka. Faktor risiko yang mereka alami adalah kondisi fisik yang menjadi lemah akibat thalassemia, penolakan dari teman sebaya, dan proses pengobatan seumur hidup. Dinamika ini menjadi fase paling kompleks dalam pembentukan resiliensi karena berperan sebagai dasar "bangunan" resiliensi. Jika dinamika pertama berjalan baik, maka tahap selanjutnya akan lebih mudah. Namun jika individu terhenti pada faktor risiko, ia tidak akan mencapai tahap resiliensi dan berhenti pada faktor risiko.

Dukungan dan kepercayaan yang diberikan oleh keluarga pada usia dini memiliki dampak signifikan bagi perkembangan psikologis manusia. Oleh karena itu, Erikson (Santrock, 2002) menempatkan fase trust versus mistrust sebagai tahap pertama perkembangan psikososial manusia. Bagi kedua responden yang menderita thalassemia, dukungan dari keluarga memiliki dampak yang lebih besar daripada orang normal. Ketika mereka terdiagnosa thalassemia, keluarga responden tetap menerima mereka. Tidak ada penolakan dari orang terdekat mereka. Bahkan mereka tetap diberikan kepercayaan untuk beraktivitas normal dan tidak memberikan perlakukan khusus kepada responden. Hal ini penting agar responden tetap merasa sebagai manusia normal dan tetap sama dengan teman-temannya yang lain.

Strategi adaptasi dikembangkan oleh responden sejalan dengan faktor kunci dukungan keluarga. Seperti yang dijelaskan oleh Shonkoff \& Meisels (2000), dalam bukunya Handbook of Early Childhood Intervention, bagi setiap anak dengan kerentanan biologis (fisik), interaksi dan peningkatan kualitas hubungan antara anak dengan orangtua (pengasuh) adalah elemen paling penting dari lingkungan. Ketika interaksi tersebut tidak berjalan positif, gangguan genetik yang dimiliki anak akan berpotensi membawa masalah yang lebih besar di kemudian hari. Tapi jika ada interaksi positif yang dibàngun, maka anak memiliki peluang untuk berkembang lebih baik di masa depan.

Setelah menjadi resilien, mereka tetap hidup dengan transfusi darah. Agar menjadi resilien, mereka terus mengembangkan faktor penentu agar efek dari faktor risiko bisa diminimalisir. Kondisi ini berbeda dengan resiliensi pada kasus kekerasan seksual atau kekerasan sosial. Faktor risiko utama yang mereka hadapi bisa hilang atau dihindari. Resiliensi pada mereka tergantung pada kemampuan untuk melupakan trauma.

Kelemahan dalam penelitian ini adalah belum adanya data observasi 
yang bisa dijadikan sebagai bahan analisis data.. Peneliti memang tidak menjadi observer yang mengikuti aktivitas responden secara utuh. Jika ada data observasi yang bisa didapatkan, analisis dan pembahasan terhadap pembentukan resiliensi pada penderita thalassemia akan lebih komprehensif. Kelemahan kedua adalah tidak adanya data wawancara dari significant other. Meskipun wawancara dari significant other tidak sebagai data utama, kehadiran data ini bisa membantu validitas data yang didapatkan dari kedua responden.

\section{KESIMPULAN}

1)Berdasarkan hasil penelitian dan pembahasan, peneliti mendapatkan satu faktor kunci penentu resiliensi dan tiga faktor penentu turünan serta tahap pembentukan resiliensi (resilient formation). Pembentukan resiliensi berawal dari kondisi tidak menguntungkan pada responden akibat kerentanan biologis (thalassemia). Kondisi ini menimbulkan kerentanan seperti fisik yang lemah. Berkat dukungan keluarga, responden berhasil mengembangkan strategi adaptasi. Dukungan keluarga ini adalah faktor kunci penentu resiliensi. Keberhasilan strategi adaptasi memperkecil risiko dari kerentanan biologis dan membawa responden pada pengobatan aktif.
2)Berikutnya adalah tahap optimalisasi empat faktor penentu resiliensi yang membantu responden menjadi resilien. Kempat faktor tersebut adalah dukungan orang terdekat, spiritual, kompetensi, dan memiliki cita-cita. Berdasarkan dimensi waktu, faktor pertama yang muncul adalah dukungan orang terdekat. Dukungan keluarga berada dalam faktor ini. Bersama dengan dukungan sahabat dan dukungan pacar, dukungan keluarga menjadi fondasi bagi kemunculan resiliensi. Kemudian ada penerimaan diri positif (bagian dari spiritual) yang diikuti oleh faktor kompetensi. Setelah responden berhasil menemukan minat dan potensinya, mereka mulai memiliki cita-cita untuk masa depan. Dengan semua keadaan yang telah terjadi, kedua responden yakin bahwa perbedaan fisik yang diberikan Tuhan kepada mereka harus dipandang sebagai anugerah, bukan ujian. Pada tahap ini, kedua responden telah mencapai tahapan keyakinan spiritual bahwa mereka telah diberikan anugerah dalam bentuk yang berbeda oleh Tuhan.

\section{SARAN}

Saran bagi responden dalam penelitian ini adalah tetap mempertahankan gaya hidup resilien dengan mengoptimalkan minat dan potensi mereka pada bidang tertentu. Pencapaian positif pada bidang tertentu akan me- 
ningkatkan kepercayaan diri penderita thalassemia untuk berkompetisi dengan orang lain.

Saran bagi orangtua penderita thalassemia adalah terus memberikan motivasi dan dukungan psikologis. Penderita thalassemia butuh dukungan dan penerimaan dari orang-orang di sekitarnya. Penderita thalassemia merasa lebih baik ketika lingkungan sosial tidak memberikan perlakukan berbeda terhadap mereka.

Resiliensi adalah kondisi psikologis yang terjadi dalam waktu relatif lama dan harus melalui beberapa tahapan. Oleh karena itu, menarik bagi peneliti berikutnya untuk meneliti pembentukan resiliensi dalam model peneltian jangka panjang (longitudinal) yang menggabungkan metode kualitatif (dengan tambahan observasi dan wawancara significant others) dan kuantitatif.

\section{DAFTAR PUSTAKA}

Adz-Dzakiey, H. B. 2007. Psikologi Kenabian: Menghidupkan Potensi dan Kepribadian Kenabian dalam Diri. Yogyakarta: Beranda Publishing. Bogar, C. B. and Killacky, D. H. 2006. Resiliency Determinants And Resiliency Processes Among Female Adult Survivors Of Childhood Sexual Abuse. Journal of Counseling \& Development $\mathrm{Vol} 86$ page $318-328$

Denzin, N. K dan Lincoln, Y.S. 2009. Handbook of Qualitative Research (Dariyatno, dkk). Yogyakarta:
Pustaka Pelajar.Everall, R. D, Altrows, J. K and Paulson, B. L. 2006. Creating a Future: A Study of Resilience in Suicidal Female Adolescents. Journal of Counseling \& Development Fall 2006 Volume 84 page 461-472.

Grotberg, E. H. 1999. Tapping Your Inner Strenght: How To Find The Resilience to Deal With Anything. Canada: New Harbinger Publications.

Hoffbrand, A.V. dkk. 2002. Kapita Selekta Hematologi (Lyana Setiawan). Jakarta: Penerbit Buku Kedokteran EGC.

Isbisten, J. P. dan Pittiglio, D. H. 1999. Hematologi Klinik: Pendekatan BerorientasiMasalah (Penterjemah: Devy H. R). Jakarta: Hipokrates.

Lena, D. dkk. 1997. Apakah Thalassemia Itu? Bagaimana Menanganinya? Jakarta: Yayasan Thalassemia Indonesia.

Majalah TEMPO. Edisi 11-17 Januari 2010. Rubrik: Penderita Bak Telepon Seluler.

Newman, W. L. 2003. Social Research Methods: Qualitative and Quantitative Approach ( $5^{\text {th }}$ Edition). Boston: Pearson Education.

Santrock, J.W. 2002. Life Span Development Perkembangan Masa Hidup Jilid I (Edisi Kelima: Achmad Chusairy). Jakarta: Erlangga.

Sarwono, S. W. 2010. Psikologi Remaja: Edisi Revisi. Jakarta: Rajawali Press.Shonkoff, J.P and 
KHAZANAH, Vol.IV No. 1 Juni 2011

Meisell, S. J. 2000. Handbook of Teoritisasi Data (M. Shodiq dan Imam Early Childhood Intervention $2^{\text {nd }}$ Muttaqien). Yogyakarta: Pustaka Edition. United Kingdom: Cambridge University Press. Pelajar.

Strauss, A; dan Corbin, J. 2003. Dasarhttp://www.inilah.com/read/detail/ Dasar Penelitian Kualitatif: Tatalangkah dan Teknik-Teknik $255741 /$ thalasemia-penyakitturunan-yang-bisa-dicegah// (diakses pada 23 Januari 2011). 